\title{
Pengaruh Produksi dan Konsumsi Terhadap Impor Beras di Provinsi Jambi Tahun 2010-2016
}

\author{
Silvia Rahayu \\ Sekolah Tinggi Ilmu Ekonomi (STIE) Sakti Alam Kerinci \\ Correspondence Email : silviarhy1038@gmail.com
}

\begin{abstract}
This study aims to determine the effect of rice production and consumption on rice imports in Jambi Province in 2010-2016 simultaneously and partially and calculate the effect of rice production and consumption on rice imports in Jambi Province in 2010-2016 simultaneously and partially. The data used in this research is secondary data. Data was analyzed using multiple lienear regression analysis. The results showed that: There is a significant influence between the variables of rice production and consumption on rice imports in Jambi Province in 2010-2016 simultaneously, this is evidenced by the calculated $F$ value $>F$ table or significance value $>\alpha$. The magnitude of the effect of rice production and consumption on rice imports in Jambi Province simultaneously is $82.2 \%$, while the remaining $17.8 \%$ is explained by other variables not examined in this study There is a significant influence between the variables of rice production on rice imports in the Province Jambi, this can be seen from the count $-t$ value of $<-t$ table which is $-3.206<-2.132$ or the significance value $<\alpha$ is $0.002<0.05$. The magnitude of the effect of the rice production variable on rice imports in Jambi Province is with the value of $\beta 1=-2,940$, meaning that if rice production increases by 1 ton, rice imports will decrease by -2,940 assuming the other variables are constant. There is a significant influence between rice consumption variables on rice imports in Jambi Province, this can be seen from the value of $t$ count $>t$ table which is $3.076>2.132$ or a significance value $<\alpha$ that is $0.004<0.05$. The magnitude of the influence of rice consumption variables on rice imports in Jambi Province is with the value of $\beta 1=$ 3.024, meaning that if rice consumption increases by 1 ton, rice imports will increase by 3.024 assuming the other variables are constant.
\end{abstract}

Keywords: Production, Consumption, Import of Rice.

\section{PENDAHULUAN}

Beras bukan hanya sekadar komoditas pangan, tetapi juga merupakan komoditas strategis yang memiliki sensitivitas politik, ekonomi dan kerawanan sosial yang tinggi. Demikian tergantungnya penduduk Indonesia pada beras maka sedikit saja terjadi gangguan produksi beras, pasokan menjadi terganggu dan harga jual meningkat. Kenyataan seperti ini membuat pemerintah orde baru (1967-1998) menjadikan beras sebagai alat tawar-menawar politik untuk mempertahankan kekuasaannya. Dalam rangka peningkatan produksi padi di Indonesia menurut Pusat Penelitian dan Pengembangan Tanaman Pangan dikembangkan dalam 5 usaha yaitu : (a) perluasan areal; (b) peningkatan produktivitas hasil; (c) peningkatan stabilitas hasil; (d) peningkatan senjang hasil dan (e) penekanan kehilangan hasil. Dari kelima usaha tersebut yang memberikan kontribusi terbesar pada peningkatan produksi adalah perluasan areal. Pada masa mendatang diharapkan kontribusi terbesar diperoleh dari peningkatan produktivitas hasil untuk memenuhi permintaan dalam negeri dan substitusi impor yang meningkat, mengingat semakin terbatasnya lahan pertanian yang ada.

Direktorat Jenderal Pajak (2012) impor beras merupakan salah satu impor barang yang dikenakan pajak tertentu yang bersifat strategis yang dibebaskan pajak pertambahan nilai (PPN). Selain itu dalam prosedur pemberian fasilitas impor beras atau barang hasil pertanian tidak menggunakan surat keterangan bebas pajak pertambahan nilai (SKB PPN), hanya barang modal yang menggunakan SKB PPN. Tujuan dari pembebasan PPN adalah untuk menjamin tersedianya barang-barang yang bersifat strategis tersebut (Direktorat Jenderal Pajak, 2012). Konsumsi beras lebih besar dari produksi beras, menunjukkan bahwa masyarakat Indonesia mayoritas makanan pokonya adalah beras. Untuk memenuhi kebutuhan konsumsi masyarakat indonesia, pemerintah melakukan impor beras. Sektor pertanian di Provinsi Jambi sekarang ini masih tetap merupakan sektor pertumbuhan ekonomi Daerah Jambi. Keadaan ini tercermin dari besarnya sumbangan sektor pertanian terhadap pembentukan PDRB (Produk Domestik Regional Bruto). Berdasarkan harga konstan tahun 1996, diketahui sumbangan sektor pertanian terhadap PDRB tahun 2007 sebesar 1.042.124 juta rupiah meningkat dari tahun 2006 yaitu 980.917 juta rupiah dengan laju perubahan sebesar 
5,87\% sedangkan sumbangan sub sektor tanaman bahan makanan terhadap PDRB tahun 2007 sebesar 369.325 juta rupiah meningkat dari tahun 2006 yaitu sebesar 366.698 juta rupiah dengan laju perubahan sebesar $0,71 \%$. (Zahari, 2018)

Krisis penyediaan pangan menjadi masalah besar dan sensistif karena semakin mahal terutama sejak terjadinya perubahan iklim global dan semakin gencarnya alih fungsi lahan produktif padi menjadi lahan kelapa sawit, termasuk yang terjadi di Provinsi Jambi. Memperhatikan data statistik produksi beras di Provinsi Jambi, dapat dikatakan ada peningkatan, tetapi jika diperhatikan laju tumbuh produktifitasnya ternyata relatif rendah. Hal ini dapat dijadikan sebagai salah satu indikator bahwa adanya pertumbuhan produksi padi tersebut dalam rangka pemenuhan kebutuhan pangan masyarakat lebih disebabkan oleh upaya ekstensifikasi dibandingkan dengan intensifikasi. Fenomena ini pada gilirannya menimbulkan masalah baru dalam konsumsi beras dikemudian hari disatu pihak mengurangi kemampuam melestarikan swasembada beras, sementara di lain pihak dapat meningkatkan ketergantungan terhadap impor. Dengan demikian, konsumsi beras rumah tangga penting diantisipasi secara cermat pada masa yang akan datang. Hal ini sejalan dengan Peraturan Presiden Nomor 7 Tahun 2005 dimana pemerintah mengambil posisi kebijakan dengan pilihan kecukupan pangan dengan menjaga ketat produksi beras dalam negeri pada tingkat ketersediaan minimal 90\% dari kebutuhan domestik bagi kemandirian pangan.

Perkembangan jumlah penduduk Provinsi Jambi pada tahun 2005 sebesar 2.399.357 jiwa meningkat menjadi 2.479.469 jiwa pada tahun 2007 dengan laju pertumbuhan jumlah penduduk sebesar 3,34\% setiap tahunnya. Demikian pula dengan pendapatan per kapita Provinsi Jambi berdasarkan harga konstan dari tahun ketahun mengalami peningkatan. Pendapatan per kapita Provinsi Jambi pada tahun 2005 sebesar Rp. 2.965.175,00- per kapita dan pada tahun 2007 berjumlah Rp. 3.171.625,00- per kapita dengan laju pertumbuhannya sebesar 6,96\% per tahun, sehingga kebutuhan konsumsi beras di Provinsi Jambi terus mengalami peningkatan sejalan dengan peningkatan jumlah penduduk dan pendapatan masyarakat. Ketersediaan beras di Provinsi Jambi berdasarkan produksi beras yang ada di dalam Provinsi Jambi. Selama 16 tahun terakhir (2000-2015) perkembangan jumlah produksi, konsumsi dan impor beras di Provinsi Jambi dapat dilihat pada Tabel 1 berikut.

Tabel 1

Jumlah Produksi, Konsumsi, Impor Beras dan Pertumbuhannya di Provinsi Jambi Tahun 2001-2016 (Ton)

\begin{tabular}{|c|c|c|c|c|c|c|}
\hline Tahun & $\begin{array}{l}\text { Produksi } \\
\text { Beras }\end{array}$ & Pertumbuhan (\%) & $\begin{array}{l}\text { Konsumsi } \\
\text { Beras }\end{array}$ & $\begin{array}{c}\text { Pertumbuhan } \\
(\%)\end{array}$ & Impor Beras & $\begin{array}{c}\text { Pertumbuhan } \\
(\%)\end{array}$ \\
\hline 2001 & 536.779 & - & 616.952 & - & 133.821 & - \\
\hline 2002 & 556.564 & 3,69 & 639.843 & 3,71 & 138.917 & 3,81 \\
\hline 2003 & 561.007 & 0,80 & 665.695 & 4,04 & 162.575 & 17,03 \\
\hline 2004 & 578.335 & 3,09 & 664.749 & $-0,14$ & 144.218 & $-11,29$ \\
\hline 2005 & 579.404 & 0,18 & 671.626 & 1,03 & 150.624 & 4,44 \\
\hline 2006 & 579.635 & 0,04 & 674.228 & 0,39 & 153.221 & 1,72 \\
\hline 2007 & 544.597 & $-6,04$ & 619.866 & $-8,06$ & 189.170 & 23,46 \\
\hline 2008 & 586.631 & 7,72 & 675.954 & 9,05 & 148.102 & $-21,71$ \\
\hline 2009 & 582.106 & $-0,77$ & 646.749 & $-4,32$ & 121.285 & $-18,11$ \\
\hline 2010 & 644.947 & 10,80 & 692.892 & 7,13 & 118.197 & $-2,55$ \\
\hline 2011 & 628.828 & $-2,50$ & 794.596 & 14,68 & 133.785 & 13,19 \\
\hline 2012 & 646.640 & 2,83 & 759.305 & $-4,44$ & 158.690 & 18,62 \\
\hline 2013 & 625.164 & $-3,32$ & 702.915 & $-7,43$ & 178.874 & 12,72 \\
\hline 2014 & 664.533 & 6,30 & 807.677 & 14,90 & 184.377 & 3,08 \\
\hline 2015 & 664.721 & 0,03 & 745.053 & $-7,75$ & 205.119 & 11,25 \\
\hline 2016 & 541.312 & $-18,57$ & 791.179 & 6,19 & 187.665 & $-8,51$ \\
\hline Jumlah & 9.521.203 & & 11.169 .279 & & 2.508.640 & \\
\hline Rata-rata & $595.075,19$ & 0,28 & 698.079,94 & 1,81 & 156.790 & 2,95 \\
\hline
\end{tabular}

Sumber : Badan Pusat Statistik Provinsi Jambi, Tahun 2017.

Tabel 1. diatas dapat dilihat bahwa ada kecenderungan jumlah produksi, konsumsi dan impor beras mengalami fluktuasi dengan laju yang naik Untuk mendukung ketersediaan pangan beras tersebut produksi pengadaan beras terutama dari sumber-sumber daerah. Pengadaan beras di Provinsi Jambi selain berasal dari 
pengadaan beras dalam daerah, juga berasal luar daerah (move nasional) serta stok (persediaan) beras dari tahun sebelumnya. Adapun tujuan pengadaan beras dari luar daerah (move nasional) adalah untuk menjamin ketersediaan beras apabila pengadaan beras dari dalam daerah Provinsi Jambi tidak mampu untuk memenuhi kebutuhan konsumsi. Impor tertinggi terjadi di tahun 2007 sebesar 23,46\% karena adanya penurunan produksi beras, sehingga menuntut pemerintah untuk mengadakan impor beras. Impor beras tidak selalu diindikasikan karena ketidakmampuan daerah dalam memproduksi beras tapi diperlukan untuk menjaga ketersediaan beras agar tidak terjadi defisit yang akan berdampak kepada kenaikan harga.

\section{Studi Pustaka}

Menurut Suryana (2002) pembangunan adalah suatu perubahan untuk mencapai tujuan tertentu. Usaha-usaha pembangunan diarahkan pada perbaikan tingkat hidup, harga diri, dan kebebasan. tujuannya adalah usaha-usaha untuk mencapai arah yang lebih baik dimasa yang akan datang dan proses tranformasi sruktural yaitu suatu proses dari pembanguan yang dilakukan oleh manusia dari kebutuhan primer, sekunder dan tersier menjadi kebutuhan pokok dalam artian kebutuhan suatu barang yang semula dianggap mewah menjadi kebutuhan biasa. Todaro (2000) berpendapat bahwa pembangunan ekonomi adalah kapasitas perekonomian nasional, yang kondisi ekonomi awalnya kurang lebih berada dalam keadaan statis untuk jangka waktu yang lama, untuk menghasilkan dan mempertahankan tingkat kenaikan produk nasional kotor (PNK) sekitar 5 sampai $7 \%$ atau lebih setahun.

Pembangunan seringkali diartikan pada pertumbuhan dan perubahan. Jadi pembangunan pertanian yang berhasil dapat diartikan terjadi pertumbuhan sektor pertanian yang tinggi sekaligus terjadi perubahan masyarakat tani dari yang kurang baik menjadi yang lebih baik. Seperti diketahui sektor pertanian di Indonesia dianggap penting. Hal ini terlihat dari peranan sektor pertanian terhadap penyediaan lapangan kerja, penyedia pangan, penyumbang devisa negara malalui ekspor dan sebagainya. Oleh karena itu wajar kalau biaya pembangunan untuk sektor pertanian ini selalu tiga besar di antara sektor-sektor yang lain (Soekartawi, 2002). Ketahanan pangan nasional tidak mensyaratkan untuk melakukan swasembada produksi pangan karena tergantung pada sumberdaya yang dimiliki. Suatu negara bisa menghasilkan dan mengekspor komoditas pertanian yang bernilai ekonomi tinggi dan barang-barang industri, kemudian membeli komoditas pangan di pasar internasional. Sebaliknya, negara yang melakukan swasembada produksi pangan pada level nasional, namun dijumpai masyarakatnya yang rawan pangan karena ada hambatan akses dan distribusi pangan (Stevens et al, 2000). Beras merupakan komoditas strategis, sehingga kebijakan perberasan menjadi penentu kebijakan pangan nasional dalam pemenuhan hak pangan dan kelangsungan hidup rakyat. Hampir semua pemerintah di dunia, selalu melakukan kontrol dan intervensi terhadap komoditas pangan strategis seperti beras untuk ketahanan pangan dan stabilitas politik. Adapun kebijakan perberasan di Indonesia terdiri dari Kebijakan Peningkatan Produksi Padi/Beras; dan Kebijakan Harga Beras.

Produksi pertanian tidak terlepas dari pengaruh kondisi alam setempat yang merupakan salah satu faktor pendukung produksi. Selain keadaan tanah yang cocok untuk kondisi tanaman tertentu, iklim juga sangat menentukan. Seperti halnya tanaman pertanian padi. Hanya pada kondisi tanah dan iklim tertentu dapat tumbuh dan berproduksi dengan baik. Keadaan tanah dapat diatasi dengan penggunaan pupuk. Oleh karena itu salah satu faktor produksi padi adalah harga pupuk, selain dari harga output padi sendiri. Iklim yang mendukung dengan curah hujan yang tinggi sangat mempengaruhi pertumbuhan padi, karena tanaman padi terkait dengan ketersediaan air. Jika curah hujan tinggi, maka ketersediaan air juga akan meningkat. Akan tetapi perlu adanya faktor pendukung lain diantara dibangunnya sarana dan prasarana pertanian (Soekartawi, 2002). Besar kecilnya produksi beras akan berpengaruh terhadap kontribusi sektor pertanian terhadap PDB. Jika PDB Indonesia meningkat maka pertumbuhan ekonomi juga akan meningkat. Untuk mengimbangi dan mengatasi kebutuhan pangan yang terus meningkat ini, petani harus meningkatkan produksi beras karena sebenarnya meskipun sebagai bahan makanan pokok beras dapat diganti atau disubstitusi oleh bahan makanan lainnya, namun beras memiliki nilai tersendiri bagi orang yang biasa makan nasi dan tidak dapat dengan mudah digantikan oleh bahan makanan yang lain (Soekartawi, 2002).

Fungsi produksi merupakan hubungan kuantitatif antara masukan dan produksi. Masukan seperti pupuk, tanah, tenaga kerja, modal, dan iklim yang mempengaruhi besar kecilnya produksi yang diperoleh. Jika bentuk fungsi produksi diketahui, maka informasi harga dan biaya yang dikorbankan dapat 
dimanfaatkan untuk menentukan kombinasi masukan yang baik. Secara matematis, fungsi produksi dapat dinyatakan sebagai berikut :

$\mathrm{Y}=\mathrm{f}(\mathrm{X} 1, \mathrm{X} 2, \mathrm{X} 3, \ldots . \mathrm{Xn})$

Dimana : $\mathrm{Y}=$ Jumlah produksi $\mathrm{Xn}=$ Faktor-faktor produksi.

Malian et.all (2004) konsumsi beras dipengaruhi oleh jumlah penduduk, harga beras di pasar domestik, impor beras tahun sebelumnya, harga jagung pipilan di pasar domestik dan nilai tukar riil. Tambahan penduduk dan melonjaknya konsumsi beras di negara-negara Afrika. Naiknya permintaan beras dari negara-negara itu menambah semakin meningkatnya pasar beras dunia. Permintaan beras makin tinggi, padahal volume beras yang di perdagangkan di pasar dunia merosot. Belum lagi dampak perubahan iklim global yang menyebabkan terjadinya perubahan musim hujan dan kemarau yang ekstrem di sejumlah negara pengekspor beras seperti Thailand, Vietnam, Pakistan, India dan China mendorong negara-negara itu lebih mementingkan stok beras untuk warganya. Hingga saat ini masih ada komitmen yang kuat, terutama dari pemerintah, untuk mempertahankan swasembada beras nasional pada masa mendatang.

Direktorat Jenderal Pajak (2012) impor beras merupakan salah satu impor barang yang dikenakan pajak tertentu yang bersifat strategis yang dibebaskan pajak pertambahan nilai (PPN). Selain itu dalam prosedur pemberian fasilitas impor beras atau barang hasil pertanian tidak menggunakan surat keterangan bebas pajak pertambahan nilai (SKB PPN), hanya barang modal yang menggunakan SKB PPN. Tujuan dari pembebasan PPN adalah untuk menjamin tersedianya barang-barang yang bersifat strategis tersebut (Direktorat Jenderal Pajak, 2012). Impor ditentukan oleh kesanggupan atau kemampuan dalam meghasilkan barang-barang yang bersaing dengan barang luar negeri. Hal ini berarti nilai impor bergantung pada tingkat nilai pendapatan nasional suatu negara. Semakin tinggi tingkat pendapatan nasional dan semakin rendah kemampuan negara tersebut dalam menghasilkan barang-barang tertentu, maka kegiatan impor pun akan semakin tinggi. Alasan suatu negara melakukan impor disebabkan adanya kegagalan negara tersebut dalam memenuhi kebutuhan dalam negeri, baik dalam bentuk kualitas maupun kuantitas. Ketidakmampuan suatu negara dalam menyediakan kebutuhan beras terjadi akibat negara tersebut tidak dapat berproduksi secara efisien. Jumlah impor terus meningkat bukan berarti dapat mencukupi kebutuhan beras di dalam negeri. Sebab jumlah penduduk Indonesia tiap tahun meningkat sehingga peningkatan jumlah impor beras dimaksudkan untuk mengimbangi peningkatan jumlah penduduk yang mengkonsumsi beras.

\section{METODE PENELITIAN}

Metode pengumpulan data dilakukan dengan Peneltian Lapangan (Field Research) Penelitian Kepustakaan (Library Research). Data yang digunakan dari dalam penelitian ini adalah data sekunder, yaitu data yang diperoleh dari informasi-informasi yang telah disediakan oleh unit-unit atau lembaga yang ada. Data diperoleh Badan Pusat Statistik (BPS) Provinsi Jambi, Dinas Pertanian dan Tanaman Pangan Provinsi Jambi dan Sumber data lainnya.

\section{Metode dan Alat Analisis Data}

Deskriptif Kualitatif dan Deskriptif Kuantitatif. Untuk mengetahui pengaruh produksi dan konsumsi terhadap impor beras di Provinsi Jambi digunakan rumus:

Analisis Regresi Berganda

$\mathrm{Y}=\mathrm{a}+\beta 1 \mathrm{X} 1+\beta 2 \mathrm{X} 2+\mathrm{e}$

Dimana : Y: Impor Beras (Ton); a : konstanta; X1 : Produksi Beras (Ton); $\beta$ : Koefisien regresi; $\mathrm{X} 2$ : Konsumsi Beras (Ton); e : error.

Koefisien Determinasi

Analisis koefisien determinasi digunakan untuk melihat berapa besar pengaruh variabel $\mathrm{X}$ terhadap variabel Y. Sedangkan kriteria pengujiannya adalah sebagai berikut :

- Apabila t hitung lebih besar dari t tabel 5\% $(\alpha=0,05)$ dan derajat kebebasan sebesar (n-k-1) maka Ho ditolak dan Ha diterima.

- Apabila t hitung lebih kecil dari t tabel 5\% $(\alpha=0,05)$ dan derajat kebebasan sebesar (n-k-1) maka Ho diterima dan Ha ditolak. 


\section{HASIL DAN PEMBAHASAN}

Menurut BPS (2015), penduduk Provinsi Jambi tahun 2014 berjumlah 3.092.265 jiwa dengan tingkat kepadatan rata-rata sebesar 61,65 jiwa/km² kecuali Kota Jambi sebesar 2.588,99 jiwa/km² dan Kota Sungai Penuh sebesar 210,20 jiwa/ $\mathrm{km}^{2}$. Sebagaimana karakter ibukota Provinsi pada umumnya yaitu sebagai pusat pemerintahan, industri dan perdagangan, maka Kota Jambi juga merupakan daerah tujuan arus migrasi.

\section{Tabel 2}

Luas Daerah, Jumlah Penduduk dan Kepadatan Penduduk di Provinsi Jambi Tahun 2016

\begin{tabular}{|c|c|c|c|c|}
\hline No. & Kabupaten/Kota & Luas Daerah $\left(\mathbf{K m}^{2}\right)$ & Jumlah Penduduk (Jiwa) & Kepadatan Penduduk (Jiwa/Km²) \\
\hline 1. & Kerinci & $3.3 .55,27$ & 229.495 & 68,40 \\
\hline 2. & Merangin & $7.679,00$ & 333.206 & 43,39 \\
\hline 3. & Sarolangun & $6.184,00$ & 246.245 & 39,82 \\
\hline 4. & Batang Hari & $5.804,00$ & 241.334 & 41,58 \\
\hline 5 . & Muaro Jambi & $5.326,00$ & 342.952 & 64,39 \\
\hline 6. & Tanjung Jabung Timur & $5.445,00$ & 205.272 & 37,70 \\
\hline 7. & Tanjung Jabung Barat & $4.649,85$ & 278.741 & 59,95 \\
\hline 8. & Tebo & $6.461,00$ & 297.735 & 46,08 \\
\hline 9. & Bungo & $4.659,00$ & 303.135 & 65,06 \\
\hline 10. & Kota Jambi & 205,43 & 531.857 & $2.588,99$ \\
\hline & Sungai Penuh & 391,50 & 82.293 & 210,20 \\
\hline \multicolumn{2}{|c|}{ Jumlah } & $50.160,05$ & 3.092.265 & \\
\hline
\end{tabular}

Sumber : Badan Pusat Statistik Provinsi Jambi, Tahun 2015.

\section{Pengaruh Produksi dan Konsumsi Beras Terhadap Impor Beras di Provinsi Jambi Tahun 2010-2016 Secara Simultan.}

Berdasarkan penelitian ini dengan menggunakan data yang diperoleh dari BPS Provinsi Jambi sebagaimana yang terlampir di lampiran satu dan diolah dengan menggunakan program SPSS vers 20.00 seperti pada tabel di bawah ini.

Tabel 3

Anova

\begin{tabular}{|l|l|l|r|r|r|r|}
\hline \multicolumn{2}{|c|}{ Model } & \multicolumn{1}{c|}{ Sum of Squares } & Df & Mean Square & F & Sig. \\
\hline 1 & Regression & 1895005187,213 & 2 & 947502593,607 & 11,952 &, $009^{\mathrm{b}}$ \\
& Residual & 3981321216,501 & 4 & 995330304,125 & & \\
& Total & 5876326403,714 & 6 & & & \\
\hline
\end{tabular}

Sumber : Data sekunder diolah, tahun 2017.

Berdasarkan Tabel 3 diatas, nilai F hitung sebesar 11,952. Sedangkan F tabel $(\alpha=0.05 ; \mathrm{db}$ regresi $=$ $2: \mathrm{db}$ residual $=4$ ) adalah sebesar 6,94. Karena $\mathrm{F}$ hitung $>\mathrm{F}$ tabel yaitu 11,952 $>6,94$ maka analisis regresi adalah signifikan. Hal ini berarti $\mathrm{HO}$ ditolak dan Ha diterima sehingga dapat disimpulkan bahwa impor beras tahun 2010-2016 dapat dipengaruhi secara signifikan oleh variabel bebas yaitu variabel produksi dan konsumsi beras. Untuk melihat berapa besar pengaruh variabel produksi dan konsumsi beras terhadap impor beras digunakan koefisien determinasi. Adapun nilai $\mathrm{R}^{2}$ (koefisien determinasi) dan koefisien korelasi (R) seperti dalam tabel berikut :

Tabel 4

Model Summary

\begin{tabular}{|l|r|r|r|r|r|}
\hline Model & R & R Square & Adjusted R Square & Std. Error of the Estimate & Durbin-Watson \\
\hline 1 &, $868^{\mathrm{a}}$ &, 822 &, 716 & 31548,85583 & \\
\hline
\end{tabular}

Sumber : Data sekunder diolah, tahun 2017.

Berdasarkan Tabel 4 didapatkan koefisien determinasi $\mathrm{R}^{2}$ sebesar ,822 Artinya bahwa 82,2\% variabel impor beras dapat dijelaskan oleh variabel bebasnya, yaitu produksi dan konsumsi beras, sisanya $17,8 \%$ dijelaskan oleh variabel lain yang tidak diteliti dalam penelitian ini. Selain koefisien determinasi, juga didapat koefisien korelasi yang menunjukkan besarnya hubungan antara variabel bebas yaitu impor beras 
dengan variabel produksi dan konsumsi beras, nilai $\mathrm{R}$ (koefisien korelasi) sebesar 86,8 nilai korelasi ini menunjukkan bahwa hubungan antara variabel produksi dan konsumsi beras dengan variabel impor beras termasuk kategori "Sangat Kuat" karena berada pada selang 0,80-1,000.

\section{Pengaruh Produksi dan Konsumsi Beras Terhadap Impor Beras di Provinsi Jambi Tahun 2010-2016 Secara Parsial.}

Uji t dikenal dengan uji parsial, yaitu untuk menguji bagaimana pengaruh masing-masing variabel bebasnya secara sendiri-sendiri terhadap variabel terikatnya yaitu produksi dan konsumsi beras terhadap impor beras di Provinsi Jambi. Uji ini dapat dilakukan dengan membandingkan $t$ hitung dengan $t$ tabel atau dengan melihat kolom signifikansi pada masing-masing t hitung, dengan melihat perhitungan SPSS pada coefficient regression. Adapun kriterianya :

- $\mathrm{HO}: \mathrm{r}=0$ : diduga tidak terdapat pengaruh yang signifikan antara variabel indenpenden terhadap variabel dependen.

Ha $: r \neq 0$ : diduga terdapat pengaruh yang signifikan antara variabel indenpenden terhadap variabel dependen.

Dapat juga dikatakan jika $t$ hitung $>\mathrm{t}$ tabel atau $-\mathrm{t}$ hitung $<-\mathrm{t}$ tabel maka hasilnya signifikan dan berarti H0 ditolak dan Ha diterima. Sedangkan jika $t$ hitung $<\mathrm{t}$ tabel atau $-\mathrm{t}$ hitung $>-t$ tabel maka hasilnya tidak signifikan dan berarti $\mathrm{H} 0$ diterima dan Ha dengan menggunakan tingkat signifikansi $(\alpha=0,05)$. Nilai $\mathrm{t}$ test disajikan dalam tabel berikut :

\section{Tabel 5}

Coefficients

\begin{tabular}{|c|c|c|c|c|c|c|}
\hline \multirow{2}{*}{\multicolumn{2}{|c|}{ Model }} & \multicolumn{2}{|c|}{ Unstandardized Coefficients } & \multirow{2}{*}{$\frac{\text { Standardized Coefficients }}{\text { Beta }}$} & \multirow{2}{*}{$\mathrm{t}$} & \multirow{2}{*}{ Sig. } \\
\hline & & $\mathrm{B}$ & Std. Error & & & \\
\hline \multirow[t]{3}{*}{1} & (Constant) & $-461886,699$ & 455753,637 & & $-1,013$ & ,013 \\
\hline & Produksi_x1 & $-2,940$ &, 779 & ,552 & $-3,206$ &, 002 \\
\hline & Konsumsi_x2 & 3,024 & ,316 &, 035 & 3,076 & ,004 \\
\hline
\end{tabular}

Sumber : Data sekunder diolah, tahun 2017.

Berdasarkan tabel 5. di atas diperoleh nilai t test antara X1 (produksi beras) dan X2 (konsumsi beras) dengan Y (impor beras) menunjukkan hasil yang diperoleh sebagai berikut :

\section{t Hitung X1 (Produksi Beras)}

Hasil t hitung X1 (produksi beras) $=3,206$ dan $\mathrm{t}$ tabel $(\alpha=0.05 ; \mathrm{db}$ residual $=4)$ adalah sebesar 2,132. Karena $t$ hitung $<\mathrm{t}$ tabel yaitu $-3,206<-2,132$ berarti dapat disimpulkan bahwa terdapat pengaruh yang signifikan antara variabel produksi beras dengan impor beras dan dapat dibuktikan dengan nilai signifikansi 0,002 , sedangkan dalam pengujian menggunakan alpha sebesar 0,05 hal ini berarti nilai signifikansi 0,002 < 0,05 maka pengaruh X1 (produksi beras) adalah signifikan. Hal ini berarti H0 ditolak dan Ha diterima atau dengan kata lain bahwa produksi beras merupakan faktor yang dapat menurunkan impor beras secara nyata.

\section{t Hitung X1 (Konsumsi Beras)}

Hasil $\mathrm{t}$ hitung X2 (konsumsi beras) $=3,076$ dan $\mathrm{t}$ tabel $(\alpha=0.05 ; \mathrm{db}$ residual $=4)$ adalah sebesar 2,132. Karena t hitung $>\mathrm{t}$ tabel yaitu 3,076 > 2,132 atau nilai signifikansi 0,004, sedangkan dalam pengujian menggunakan alpha sebesar 0,05 hal ini berarti nilai signifikansi $0,004<0,05$ maka terdapat pengaruh yang signifikan antara X2 (konsumsi beras) terhadap impor beras. Hal ini berarti H0 ditolak dan Ha diterima, sehingga dapat disimpulkan bahwa impor beras dapat dipengaruhi secara signifikan oleh variabel konsumsi beras atau dengan kata lain bahwa konsumsi beras merupakan faktor yang dapat meningkatkan impor beras secara nyata.

Berdasarkan pada Tabel di atas diperoleh persamaan regresi dan besarnya pengaruh nilai variabel $\mathrm{X} 1, \mathrm{X} 2$ dan Y sebagai berikut :

$Y=-461886,699-2,940 X 1+3,024 X 2$ 
- $\quad$ a = -461886,699 merupakan nilai konstanta, yaitu jika produksi dan konsumsi beras bernilai nol, maka impor beras sebesar $-461886,699$.

- $\quad \beta 1=$ Nilai koefisien regresi produksi beras sebesar -2,940, jika produksi beras meningkat sebesar 1 ton maka impor beras akan menurun sebesar -2,940 dengan asumsi variabel yang lainnya konstan.

- $\quad \beta 2=$ Nilai koefisien regresi konsumsi beras sebesar 3,024, jika konsumsi beras meningkat sebesar 1 ton maka impor beras akan meningkat sebesar 3,024 dengan asumsi variabel yang lainnya konstan.

Berdasarkan interpretasi di atas, dapat diketahui besarnya kontribusi variabel bebas terhadap variabel terikat, antara lain produksi beras sebesar -2,940 dan konsumsi beras sebesar 3,024. Sehingga dapat disimpulkan bahwa produksi beras (X1) berpengaruh negatif terhadap impor beras atau apabila produksi beras (X1) meningkat, maka akan diikuti penurunan impor beras. Sedangkan konsumsi beras berpengaruh positif terhadap impor beras atau apabila konsumsi beras (X2) meningkat, maka akan diikuti peningkatan impor beras.

\section{SIMPULAN}

Berdasarkan analisis data dan pembahasan diatas maka diperoleh kesimpulan sebagai berikut :

1. Terdapat pengaruh yang signifikan antara variabel produksi dan konsumsi beras terhadap impor beras di Provinsi Jambi tahun 2010-2016 secara simultan, hal ini dibuktikan dengan nilai F hitung > F tabel atau nilai signifikansi $>\alpha$.

2. Besarnya pengaruh produksi dan konsumsi beras terhadap impor beras di Provinsi Jambi secara serentak adalah sebesar $82,2 \%$, sedangkan sisanya $17,8 \%$ dijelaskan oleh variabel lain yang tidak diteliti dalam penelitian ini

3. Terdapat pengaruh yang signifikan antara variabel produksi beras terhadap impor beras di Provinsi Jambi, hal ini terlihat dari nilai $-t$ hitung $<-t$ tabel yaitu $-3,206<-2,132$ atau nilai signifikansi $<\alpha$ yaitu $0,002<0,05$.

4. Besarnya pengaruh variabel produksi beras terhadap impor beras di Provinsi Jambi adalah dengan nilai $\beta 1=-2,940$, artinya jika produksi beras meningkat sebesar 1 ton maka impor beras akan menurun sebesar -2,940 dengan asumsi variabel yang lainnya konstan.

5. Terdapat pengaruh yang signifikan antara variabel konsumsi beras terhadap impor beras di Provinsi Jambi, hal ini terlihat dari nilai t hitung $>\mathrm{t}$ tabel yaitu 3,076 $>2,132$ atau nilai signifikansi $<\alpha$ yaitu $0,004<0,05$.

6. Besarnya pengaruh variabel konsumsi beras terhadap impor beras di Provinsi Jambi adalah dengan nilai $\beta 1=3,024$, artinya jika konsumsi beras meningkat sebesar 1 ton maka impor beras akan meningkat sebesar 3,024 dengan asumsi variabel yang lainnya konstan.

\section{DAFTAR PUSTAKA}

Adisetiawan, R., and Yunan Surono, 2016, Indonesia Capital Market Efficiency, British Journal of Economics, Finance and Management Sciences, 11(1), 108-121

Adisetiawan, R., 2017, Does Stock Option Force Bid-Ask Spread and Abnormal Return?, International Research Journal of Finance and Economics, (161), 96-104

Asmas., Denny, Hasminidiarty, dan Adisetiawan, R., 2018, Struktur Modal dan Variabel yang Mempengaruhinya, JMAS (Jurnal Manajemen dan Sains), 3(2), 237-250

Badan Pusat Statistik Provinsi Jambi. 2017. Jambi Dalam Angka.

Malian et. all. 2004. Analisis Dampak Kebijakan Harga Dasar Padi dan Subsidi

Pupuk terhadap Permintaan dan Penawaran Beras di Indonesia. Institut Pertanian Bogor, Bogor.

Soekartawi. 2002. Prinsip-prinsip Dasar Ekonomi Pertanian, Teori dan Aplikasinya. Fakultas Pertanian Brawijaya : Malang.

Stevens et al. 2000. Theory Of Rice Consumption. Harper and Row Publisher, Inc. Great Britain.

Suryana.A dan Mardianto Krisnamurti. 2001. Bunga Rampai Ekonomi Beras. Jakarta : Fakultas Ekonomi, Universitas Indonesia.

Todaro, Michael, P . 2000. Pembangunan Ekonomi. Bumi Aksara : Jakarta.

Zahari, M., 2018, Pengaruh Pajak Daerah dan Retribusi Daerah Terhadap Belanja Modal di Kota Jambi, Jurnal Ilmiah Universitas Batanghari Jambi, 18(3), 635-646 